\title{
Cofiduciary Contribution and Indemnification in ERISA: Not Implicit Remedies
}

\author{
Rafael Ramos Aguirre*
}

\section{INTRODUCTION}

The growth in size and number of employee benefit plans led Congress to enact the Employee Retirement Income Security Act (ERISA) in the mid-1970s. ${ }^{1}$ Among other things, ERISA mandates certain standards of conduct and responsibility from fiduciaries of employee benefit plans and provides appropriate civil remedies to protect the interests of participants and beneficiaries in the plans. ${ }^{2}$ Cofiduciary contribution and indemnification, however, are not explicitly set forth in ERISA. ${ }^{3}$

While the Supreme Court has not addressed the ERISA cofiduciary contribution question directly, it held in Texas Industries, Inc. v. Radcliff Materials, Inc., ${ }^{4}$ that a right of contribution may generally arise in one of two ways: (1) through an act of Congress, express or implicit, or (2) through the power of federal courts to fashion the statute's federal common law. ${ }^{5}$ It is this analysis that courts should employ when determining whether cofiduciaries may bring claims for contribution or indemnification. This Comment addresses a circuit split on ERISA cofiduciary contribution, with a critique of the analyses that the courts employed. $^{6}$

\footnotetext{
* J.D., 2019, University of Kansas School of Law; B.A., 2016, Kansas State University. I would like to thank my wife Clare for patiently dealing with my late nights and Eva, who, as a newborn, had no other choice but to stay up with me and learn about ERISA.

1. 29 U.S.C. $§ 1001$ (a) (2012).

2. Id. $\S 1001(\mathrm{~b})$.

3. See Chemung Canal Tr. Co. v. Sovran Bank/Md., 939 F.2d 12, 15 (2d Cir. 1991) ("In ERISA, congress never dealt with contribution expressly, so the question is whether such a right can be recognized either by implication from the statute, or as a part of federal common law.").

4. 451 U.S. 630 (1981).

5. Id. at 638 (citing Nw. Airlines, Inc. v. Transp. Workers, 451 U.S. 77, 90-91 (1980)). Texas Industries examined the issue under the antitrust statutes, whereas Northwest examined the question under the Equal Pay Act of 1963 and Title VII of the Civil Rights Act of 1964.

6. Compare Chemung Canal Tr. Co., 939 F.2d at 18 (holding there are such remedies), and Chesemore v. Fenkell, 829 F.3d 803, 807 (7th Cir. 2016) (same), with Travelers Cas. \& Sur. Co. of Am. v. IADA Servs., Inc., 497 F.3d 862, 863 (8th Cir. 2007) (holding there are no such remedies),
} 
By applying the groundwork laid out by the Supreme Court in Texas Industries, the Eighth and Ninth Circuits came to the correct conclusion in declining to find cofiduciary contribution and indemnification in ERISA. Nonetheless, even in coming to the correct conclusion, both courts' analyses left more to be desired. Each court approached the question with its own structure for the analysis. This structure resulted in differing rationales for the holdings even among circuit courts which arrived at the same conclusion. If, instead, the circuit courts followed Supreme Court guidance, their opinions would have aligned more closely, and perhaps more of the circuit courts would have reached the correct conclusion.

Because cofiduciary contribution and indemnification are not found explicitly in ERISA, courts must find those remedies implicitly. Thus, the courts should also have applied the step-by-step set of guidelines established by the Supreme Court for this purpose in Touche Ross \& Co. $v$. Redington, ${ }^{7}$ in determining that ERISA does not provide for cofiduciary contribution and indemnification. ${ }^{8}$

The circuit courts that have analyzed the issue have done so in different ways-boldly immersing themselves into the sea of congressional intent, which is itself mired by additional considerations concerning statutory construction, legislative history, and the assumedly well-fashioned arguments of two opposing counsel. This alone should not have proved to be too difficult, but for the fact that courts have the ability to develop ERISA through their construction of a federal common law. This latter point seems to have thrown an otherwise straightforward analysis into disarray. Nonetheless, like ERISA's structured statutory makeup, any legal analysis of its issues should likewise be structured.

Many courts examining the ERISA contribution issue - especially the lower courts-generally make no distinction between contribution and indemnification. ${ }^{9}$ This is because the arguments for and against such cofiduciary remedies generally do not consider whether one is more

\footnotetext{
and Kim v. Fujikawa, 871 F.2d 1427, 1432-34 (9th Cir. 1989) (same).

7. 442 U.S. 560, 575-76 (1979) (citing Cort v. Ash, 422 U.S. 66, 78 (1975)).

8. Id. at 576 .

9. See Chemung, 939 F.2d at 15-18 (holding ERISA may provide a cause of action for contribution or indemnity after focusing its analysis on whether contribution is an appropriate equitable remedy); Chesemore, 829 F.3d at 811-13 (revisiting the question of whether indemnification is an appropriate equitable remedy under ERISA and coupling both indemnity and contribution in holding that they are appropriate remedies); Travelers, 497 F.3d at 863-67 (holding that contribution, indemnity, and restitution claims are not available under ERISA, but solely analyzing the contribution remedy); Kim, 871 F.2d at 1434 (dismissing a third-party claim for contribution or indemnity under ERISA after holding that ERISA does not recognize a right of contribution).
} 
appropriate than the other. Instead, the arguments couple them together since both cofiduciary contribution and indemnification would need to be implied into the statute as neither is explicitly found therein. It may also be that this intentional oversight is due to the fact that plaintiffs bring suit under both remedial theories, given that, one, they cannot be sure of which one will be available to them and, two, a plaintiff can only have one of the remedies and not both. ${ }^{10}$ Finally, note that the contribution and indemnity remedies discussed in this Comment are limited to those remedies available by court decision rather than those that are established by contract. ${ }^{11}$

\section{BACKGROUND}

\section{A. A Roadmap to the Current Circuit Split}

The circuit courts that have addressed ERISA cofiduciary contribution and indemnification have come up short in their analyses. These courts provided little structure or substance for their neighboring bar members to use in their own attempts at advocacy on either side of the argument. The Second and Seventh Circuits have found ERISA to allow cofiduciary contribution and indemnification. ${ }^{12}$ The Eighth and Ninth Circuits have declined to do so. ${ }^{13}$ What follows is a discussion of how they got there.

\section{The Second Circuit}

Chemung Canal Trust Co. v. Sovran Bank/Maryland, ${ }^{14}$ started as do all too many of these ERISA cases: the trustee, an individual, made poor

10. George L. Flint, Jr. \& Philip W. Moore, Jr., ERISA: A Co-Fiduciary Has No Right to Contribution and Indemnity, 48 S.D. L. REV. 7, 7-8 (2003).

11. See id. at 8 ("Contribution and indemnity may be a contractual obligation or imposed by a court without agreement.").

12. See Chemung, 939 F.2d at 16 ("We thus conclude that the traditional trust law right to contribution must also be recognized as a part of ERISA."); Chesemore, 829 F.3d at 812 ("We addressed this issue long ago and held that ERISA's grant of equitable remedial power and its foundation in principles of trust law permit the courts to order contribution or indemnification among cofiduciaries based on degrees of culpability.") (citing Free v. Briody, 732 F.2d 1331, 1337 (7th Cir. 1984)).

13. See Travelers, 497 F.3d at 866 ("Nor are we persuaded to infer that Congress inadvertently omitted a right to contribution from ERISA's remedial scheme. The statute pays specific attention to the rights and obligations of fiduciaries in some respects, but makes no reference to a right of contribution."); Kim, 871 F.2d at 1434 ("Fujikawa's third-party claim necessarily fails since ERISA, the governing substantive law, does not recognize a right of contribution.").

14. 939 F.2d 12 (2d Cir. 1991). 
investment decisions on behalf of an ERISA plan for Fairway Spring Company ("Fairway"). ${ }^{15}$ Fairway removed the original trustee within three years and replaced him with Sovran Bank, but the poor investments did not begin to surface for another two years, at which time Fairway replaced Sovran Bank with Chemung Canal Trust. ${ }^{16}$ Chemung then brought an action against Sovran Bank alleging a breach of fiduciary duty for "lack of prudence" and for failing to do their due diligence regarding the original investments and other questionable investments made by Sovran Bank. ${ }^{17}$ Sovran Bank promptly countersued everyone that could possibly be considered a fiduciary for the plan, including Chemung and Fairway, arguing that if Sovran Bank had lacked prudence, so had the others in managing the initial bad investments and the fallout thereafter. ${ }^{18}$ Sovran Bank also requested contribution and indemnity in case it were to be found liable. ${ }^{19}$ The district court quickly dismissed Sovran Bank's claims for fiduciary liability on the part of the other parties because, as a former fiduciary, Sovran Bank lacked standing to sue. ${ }^{20}$

The district court then proceeded to analyze the contribution and indemnification question by first citing the Supreme Court's instructions for where to find such remedies: either through congressional intent as implied in the statute or through federal common law. ${ }^{21}$ Looking first for congressional intent, the district court found none after relying primarily on the methodology used in Supreme Court case Cort v. Ash ${ }^{22}$ for determining whether a private right of action should be implied from a statute. $^{23}$ The district court then looked at whether it could create such remedies by using the federal common law. ${ }^{24}$ After examining Supreme

15. Id. at 13

16. Id.

17. Id. at $13-14$.

18. Id. at 14

19. $I d$.

20. Id.

21. Chemung Canal Tr. Co. v. Sovran Bank/Md., 753 F. Supp. 81, 84 (W.D.N.Y. 1990) (citing Tex. Indus., Inc. v. Radcliff Materials, Inc., 451 U.S. 630, 638 (1981)), aff'd in part, rev'd in part, 939 F.2d 12 (2d Cir. 1991).

22. 422 U.S. 66, 78 (1975).

23. Chemung, 753 F. Supp. at 85 . While the district court did not explicitly invoke the Cort $v$. Ash test, it examined factors that were described by the Supreme Court in Cort v. Ash. The Second Circuit described the district court's methodology in applying the Cort v. Ash test. See Chemung, 939 F.2d at 15 (stating that the district court relied primarily on the methodology of Cort v. Ash); see also Cort v. Ash, 422 U.S. 66, 78 (1975) (describing four factors in determining whether a private remedy is implicit in a statute).

24. Chemung, 753 F. Supp. at $85-86$. 
Court precedent, the district court held that "courts may develop substantive common law under ERISA only where it is consistent with congressional intent." ${ }^{25}$ Having found no such intent, it declined to develop such remedies. ${ }^{26}$

The Second Circuit respectfully disagreed with the district court's analysis. While it affirmed the district court's holding on the question of standing, it bypassed all congressional intent tests by stating that contribution is not a "right of action" but rather a "procedural device for equitably distributing responsibility for a plaintiff's losses." ${ }^{27}$ In this manner, the court jumped to a federal common law analysis and distinguished ERISA from other areas of law in which the Supreme Court had been reluctant to formulate a right of contribution. ${ }^{28}$ Unlike antitrust law, the Equal Pay Act, and Title VII, the court held that ERISA's "legislative history and the statute itself clearly contemplate development of a federal common law." ${ }^{29}$ It then further distinguished the case from Massachusetts Mutual Life Insurance Co. v. Russell, ${ }^{30}$ where the Supreme Court declined to create new substantive remedial rights, by pointing out that Russell dealt with "extracontractual, compensatory and punitive damages," and not common law remedies. ${ }^{31}$ As to why there is no mention of contribution or indemnification in the statute, the court reasoned that Congress focused its attention on the "welfare of the plan's participants and beneficiaries," intending for courts to "fill any gaps," such as the allocation of liability among cofiduciaries, by looking to "trust law principles." 32 Thus, it concluded that contribution and indemnification are available remedies under ERISA. ${ }^{33}$ The Supreme Court denied certiorari, but three justices were open to examining the question. ${ }^{34}$

25. Id. at 86

26. Id.

27. Chemung, 939 F.2d at 15 .

28.Id. at 16

29. Id. at 17 (distinguishing Chemung from Texas Indus., Inc. v. Radcliff Materials, Inc., 451 U.S. 630 (1981) (antitrust laws) and Nw. Airlines, Inc. v. Transp. Workers Union of Am., 451 U.S. 77 (1981) (Equal Pay Act and Title VII)).

30. 473 U.S. 134 (1985).

31. Chemung, 939 F.2d at 17-18 (citing Mass. Mut. Life Ins. Co. v. Russell, 473 U.S. 134, 138 (1985)).

32. Id. at 18 .

33. Id.

34. See Fairway Spring Co. v. Sovran Bank/Md., 505 U.S. 1212 (1992); see also Chemung Canal Tr. Co. v. Sovran Bank/Md., 939 F.2d 12 (2d Cir. 1991), cert. denied, 505 U.S. 1212 (1992) (No. 91-6891). Justices White, Blackmun, and O'Connor would have granted certiorari. 


\section{The Seventh Circuit}

In Chesemore v. Fenkell, the Seventh Circuit dealt with another ERISA tale of woe: a failed Employee Stock Ownership Plan (ESOP). ${ }^{35}$ The defendant, Fenkell, had made a business of buying closely-held companies which were partially owned by an ESOP, folding the acquired ESOP into his own company's ESOP, and then spinning off the acquired company at a profit some time later. ${ }^{36}$ In this particular endeavor, however, he bought a business in 2002 that later in 2006 no one had any interest in buying at a higher price. ${ }^{37}$ Not to be discouraged, he spun off the previously acquired business in a series of transactions that resulted, amongst many things, in the new company establishing an ESOP to buy out all of Fenkell's interests in the previously acquired company. ${ }^{38}$ To accomplish this end, the new business' ESOP took out a massive loan while collateralizing all the employees' accounts in the new ESOP. ${ }^{39}$ Then 2008 came along, and with it the Great Recession, and soon enough the stock in the new ESOP was worthless as the ESOP struggled to pay off its loan. ${ }^{40}$ The now empty-handed employees sued all the fiduciaries that had been in charge of looking after their best interests throughout these transactions, including the trustees that Fenkell hand-picked to ensure the sale occurred on his terms. ${ }^{41}$ Not surprisingly, the district court found Fenkell liable, which he did not contest, and also ordered him to indemnify his cofiduciaries who had been "mere musicians" to his orchestral conduction. ${ }^{42}$ Fenkell appealed. ${ }^{43}$

The Seventh Circuit looked to ERISA § 502(a)(3) which "broadly permits the court to fashion 'appropriate equitable relief' in response to a claim." ${ }^{44}$ It noted that because ERISA generally incorporated the law of trusts, the courts were able to incorporate equitable remedies under trust law - of which indemnification and contribution were two. ${ }^{45}$ The court then addressed the argument that since ERISA $\S$ 409(a) limits fiduciary liability to a plan, the implication is that a fiduciary cannot be made

\footnotetext{
35. 829 F.3d 803, 806-07 (7th Cir. 2016).

36. Id. at 806 .

37. Id.

38. Id. at $806-07$.

39. Id. at 807 .

40. Id.

41. Id.

42. Id. at 811 .

43. Id. at 807 .

44. Id. at 811 .

45. Id. at $811-12$.
} 
liable to another cofiduciary. ${ }^{46}$ The court dismissed this argument, explaining that it previously denied such an implication because of ERISA's "grant of equitable remedial power" to the courts and "its foundation in principles of trust law."

In Free v. Briody, the Seventh Circuit determined that although ERISA $\S 405$ allows for cofiduciaries to allocate duties, and thus liability, this provision was not the exclusive means of allocating liability. ${ }^{48}$ Here again, Congress intended to codify principles of trust law into ERISA, so the Seventh Circuit held that the courts have the power to borrow from those principles under appropriate circumstances and to apportion "damages equitably between the wrongdoers." Finally, addressing Russell's limitation on ERISA remedies, the court distinguished Russell similar to how the Second Circuit distinguished Russell, explaining that it only referred to extracontractual damages and not equitable remedies. ${ }^{50}$ The Seventh Circuit thus affirmed the district court's order of indemnification. ${ }^{51}$ Fenkell petitioned for certiorari, but the writ was dismissed before the United States Supreme Court came to it. $^{52}$

\section{The Eighth Circuit}

In the Eighth Circuit, Travelers Casualty \& Surety Co. of America v. IADA Services, Inc. began with a Department of Labor (DOL) audit and allegations of prohibited transactions between a trust and IADA Services, who was the employer of some of the trustees. ${ }^{53}$ The trustees, who allowed the prohibited transactions to occur, settled, and Travelers, as their insurer, bore the whole cost of the settlement. ${ }^{54}$ Travelers then sued IADA Services to recover some of what they had paid out under theories of contribution and indemnification. ${ }^{55}$ The district court declined awarding Travelers those remedies, finding that neither the statute nor federal common law made them available. ${ }^{56}$

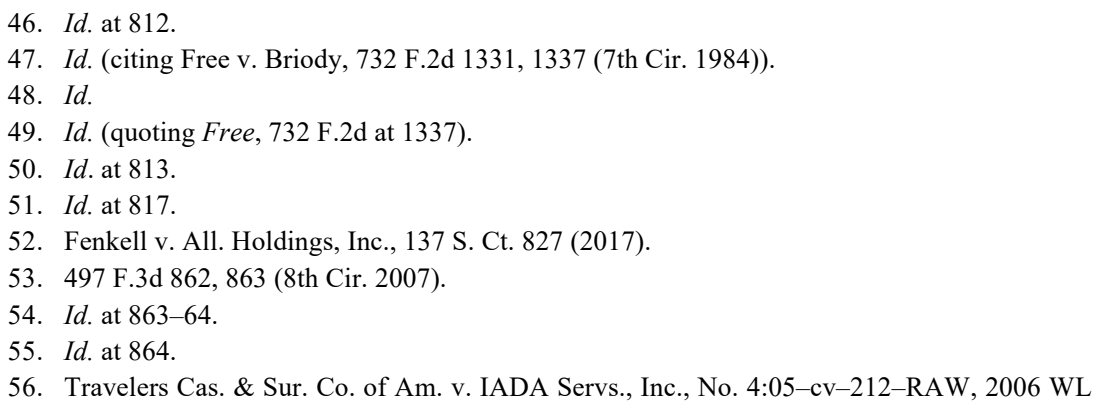


On appeal, the Eighth Circuit began its analysis by examining whether "ffederal common law'... should provide that an ERISA fiduciary found liable... may bring an action for contribution against another fiduciary that allegedly bears some responsibility for the violations." "57 In doing so, the court noted "that the Supreme Court has declined to recognize a federal common law right of contribution under three other federal statutes." ${ }^{28}$ The appellant then raised similar arguments as those in Chemung, and tried to distinguish ERISA by explaining that, unlike antitrust or other areas of law, Congress expected that federal courts would develop a federal common law, which, when guided by the common law of trusts, would allow them to recognize a right of contribution among cofiduciaries. ${ }^{59}$ The Eighth Circuit replied that such an approach was an overstatement of its authority to develop ERISA common law. ${ }^{60}$ In general, while courts did have such authority, "the Supreme Court has emphasized time and again that the statute's carefully crafted and detailed enforcement scheme provides strong evidence that Congress did not intend to authorize other remedies that it simply forgot to incorporate expressly." ${ }^{\circ 1}$ Further, it held that Congress's intent for the development of ERISA common law was not enough by itself to specifically allow for contribution, even if it such a remedy was available under trust law. ${ }^{62}$ The Eighth Circuit pointed to admiralty law, another common law area that in some circumstances may allow an action for contribution, but for which the Supreme Court had refrained from allowing such a remedy when it "might interfere with an interrelated statutory scheme." $" 63$

The Eight Circuit then addressed Travelers's suggestion that statutorily there was a way for it to recover from a cofiduciary. Travelers

$8437388, * 3-4$ (S.D. Iowa May 26, 2006).

57. Travelers, 497 F.3d at 864 (quoting Pilot Life Ins. Co. v. Dedeaux, 481 U.S. 41, 56 (1987)).

58. Id.

59. Id. at $864-65$.

60. Id. at 865 .

61. Id. (internal quotation marks and citations omitted).

62. Id. at $864-65$.

63. Id. at 865-66 (citing Halcyon Lines v. Haenn Ship Ceiling \& Refitting Corp., 342 U.S. 282, 285-86 (1952)). In Halcyon, the Supreme Court declined to allow contribution in maritime law where although it was "freer than common-law courts in fashioning rules.... Congress ha[d] already enacted much legislation in the area of maritime personal injuries." Halcyon, 342 U.S. at 285. Thus, it concluded that "the solution of this problem should await congressional action." Id. Thereafter, Congress did act, amending the Longshoremen's and Harbor Workers' Compensation Act twenty years later. See George K. Fuiaxis, Note, Indemnification or Comparative Fault: Should a Tortfeasor's Right to Receive "Ryan Indemnity" in Maritime Law Sink or Swim in the Presence of Comparative Fault?, 67 FORDHAM L. REV. 1609, 1622-35 (1999) (first describing Halcyon then the rise of Ryan's Indemnity and eventually Congress's amendments). 
argued that ERISA $\S 409$ (a) subjected a breaching fiduciary to "such other equitable or remedial relief as the court may deem appropriate"and therefore such appropriate relief should be contribution. ${ }^{64}$ The court replied that such remedies should be read in favor of the plan's benefit, and not "in favor of a breaching fiduciary." 65 Next, it batted away any inference that Congress inadvertently forgot to include contribution in its remedial scheme, concluding that ERISA was too comprehensive for that to be the case. ${ }^{66}$ Finally, it considered some policy arguments, but explained that such considerations were best left to the legislative process. ${ }^{67}$ The Eighth Circuit affirmed the district court's holding. ${ }^{68}$

\section{The Ninth Circuit}

The Ninth Circuit was the first circuit to address the ERISA contribution question in Kim v. Fujikawa, which involved a multiemployer collective bargaining plan. ${ }^{69}$ It began when the employer trustee, Kim, became aware that some union trustees on the outer islands of Hawaii were actively engaged in performing union work. ${ }^{70}$ Because the plan had been paying for their services, their engagement in union work made those payments prohibited transactions. ${ }^{71}$ Kim sued Fujikawa along with the other outer island union trustees, alleging a breach of fiduciary duty and liability for all the payments. ${ }^{72}$ The parties were found liable, ${ }^{73}$ and Fujikawa satisfied the judgment. ${ }^{74}$ The judgment, however, only covered the prohibited transactions up to trial, and Kim brought another suit to recover the prohibited transactions that were paid out between the trial and the judgment. ${ }^{75}$ This time, Fujikawa counterclaimed, seeking a right of contribution from Kim for participating in the maintenance of the prohibited practice. ${ }^{76}$ The district

\footnotetext{
64. Travelers, 497 F.3d at 866 (quoting ERISA § 409(a), 29 U.S.C. § 1109(a) (2012)).

65. Id. (quoting Kim v. Fujikawa, 871 F.2d 1427, 1432 (9th Cir. 1989)).

66. Id.

67. Id. at $866-67$.

68. Id. at 868 .

69. 871 F.2d 1427, 1428-29 (9th Cir. 1989).

70. Id. at 1429. Coincidentally, this only came to the attention of the employer trustee after he was informed that the union trustees were in charge of a strike on the outer islands. Id.

71. Id. at $1429-30$.

72. See id. at 1429.

73. Id.

74. Id. at 1431.

75. Id. About four months elapsed between trial and when the court rendered a judgment.

76. Id.
} 
court dismissed his counterclaim, and Fujikawa appealed. ${ }^{77}$

The Ninth Circuit's analysis was brief. It quickly dismissed Fujikawa's contention that contribution was a broad and equitable remedy provided for in the latter half of ERISA $\S 409$ (a) ${ }^{78}$ It stated that the particular statute only established remedies for the benefit of the plan and not a breaching fiduciary. ${ }^{79}$ Furthermore, it noted that due to ERISA's overall comprehensiveness and reticulation, "it seem[ed] clear that 'Congress did not intend to authorize other remedies [under ERISA] that it simply forgot to incorporate expressly." " 80 This was especially true, the court continued, when:

[T] he party seeking contribution is a member of the class [e.g., fiduciaries] whose activities Congress intended to regulate for the protection and benefit of an entirely distinct class [e.g., ERISA plans], and where there is no indication in the legislative history that Congress was concerned with softening the blow on joint wrongdoers. ${ }^{81}$

The court therefore affirmed the district court opinion. ${ }^{82}$ The Ninth Circuit reiterated its position on cofiduciary contribution four months later in Call v. Sumitomo Bank of California, but without any analysis as it relied on Kim for the determination. ${ }^{83}$

While the four circuits examined the same question, whether a court ruled in favor of or against contribution and indemnification depended on the amount of latitude the court gave itself to interpret ERISA and its powers under federal common law. ${ }^{84}$ Additionally, it is possible the specific case facts may have played a role in influencing the courts' decisions. The Ninth Circuit dealt with union trustees that supported a union strike and then sought contribution from the employer trustees (whom, we can assume, represented the very people the defendants were striking against). ${ }^{85}$ The Eighth Circuit dealt with an insurance company

77. Id. at 1432 .

78. Id. $1432-33$.

79. Id. at 1432 (citing Mass. Mut. Life Ins. Co. v. Russell, 473 U.S. 134, 146 (1985)).

80. Id. (quoting Russell, 473 U.S. at 145).

81. Id. at 1433 (quoting Tex. Indus., Inc. v. Radcliff Materials, Inc., 451 U.S. 630, 639 (1981)) (internal quotation marks omitted).

82. Id. at 1436.

83. 881 F.2d 626, 630-31 (9th Cir. 1989).

84. Compare Chesemore v. Fenkell, 829 F.3d 803, 811-12 (7th Cir. 2016) (finding that "ERISA's grant of equitable remedial power ... permit[s] the courts to order contribution or indemnification among cofiduciaries"), with Travelers Cas. \& Sur. Co. of Am. v. IADA Servs., Inc., 497 F.3d 862, 864-65 (8th Cir. 2007) (finding that ERISA's detailed enforcement scheme shows Congress did not intend to recognize a right of contribution)

85. Kim, 871 F.2d at 1431 . 
that tried to place some of the blame on the individuals it had been paid to insure. ${ }^{86}$ In both cases, these were not sympathetic parties. On the other hand, the Seventh Circuit allowed the defendants to recover from an individual who orchestrated the whole disaster, ${ }^{87}$ and the Second Circuit analyzed a scenario in which the plan dealt with a revolving door of trustees and administrators who all may or may not have had a hand in its poor administration. ${ }^{88}$

Nonetheless, the Supreme Court in Texas Industries established precedent providing instructions for determining whether a claim for contribution may be implied in a statute and limitations on how courts may develop federal common law. ${ }^{89}$ The circuit courts should have approached the issue using this uniform analysis, which, when properly applied, should have led them to hold that ERISA does not allow for claims for contribution or indemnification.

\section{B. Finding a Cause of Action Where There Is None Explicitly Stated}

The Supreme Court has held that a right of contribution may arise in one of two ways: (1) through an act of Congress, expressly or implicitly, or (2) through the power of federal courts to fashion the statute's federal common law. ${ }^{90}$ It is this analysis that courts should employ when determining whether cofiduciaries may bring claims for contribution or indemnification.

This two-part approach originated in 1981 in Northwest Airlines, Inc. v. Transport Workers Union of America, where the Court employed the analysis in determining there was no right to contribution under the Equal Pay Act and Title VII. ${ }^{91}$ Later, in Texas Industries, Inc. v. Radcliff Materials, Inc., the Supreme Court again employed the analysis in determining there was no right to contribution under antitrust law. ${ }^{92}$ A little while later, in Musick, Peeler \& Garrett v. Employers Insurance of Wausau, the Court distinguished the applicability of the test depending

86. Travelers, 497 F.3d at 864 .

87. Chesemore, 829 F.3d at 807.

88. Chemung Canal Tr. Co. v. Sovran Bank/Md., 939 F.2d 12, 13-14 (2d Cir. 1991).

89. Tex. Indus., Inc. v. Radcliff Materials, Inc., 451 U.S. 630, 640-46 (1981).

90. Id. at 638 (citing Nw. Airlines, Inc. v. Transp. Workers Union of Am., 451 U.S. 77, 90-91 (1981)). Texas Industries examined the issue under the antitrust statutes; Northwest Airlines had examined the question under the Equal Pay Act of 1963 and Title VII of the Civil Rights Act of 1964. Id.

91. Nw. Airlines, 451 U.S. at 90-91.

92. Tex. Indus., Inc., 451 U.S. at 646. 
on the act to which the courts were applying the test. ${ }^{93}$ In Musick, the Court found that the right to contribution is available under Rule 10b-5 of the Securities Exchange Act. ${ }^{94}$ However, the Court did so because, unlike in Texas Industries and Northwest Airlines, the statute in Musick was not "express in creating the substantive damages liability for which contribution was sought." 95 The dissent, on the other hand, rejected such a distinction and, using the normal test, came to the opposite conclusion. $^{96}$ Even circuit courts have acknowledged this analysis as the appropriate one for determining whether a remedy for contribution should be available. ${ }^{97}$

ERISA creates liability under express remedial provisions, provides for substantive damages, and establishes a way for fiduciaries to limit

93. Musick, Peeler \& Garrett v. Emp'rs Ins. of Wausau, 508 U.S. 286, 298 (1993)

94. Id.

95. Id. at 290-91.

96. Compare id. at 292-97 (quoting Va. Bankshares, Inc. v. Sandberg, 501 U.S. 1083, 1104 (1991)) (flipping the analysis on its head by starting first with determining that "'where a legal structure of private statutory rights has developed without clear indications of congressional intent,' a federal court has the limited power to define the "contours of that structure"" to show that the court had the authority to establish federal common law; and then secondly looking for what "Congress might have done" based on several sections that allow for rights of contribution in the case of other violations), with id. at 302 (Thomas, J., dissenting) ("The proper analysis flows from our wellestablished approach to implied causes of action in general and to implied rights of contribution in particular. When deciding whether a statute confers a private right of action, we ask whether Congress - either expressly or by implication - intended to create such a remedy. Where Congress did not expressly create a contribution remedy, we may infer that Congress nevertheless intended by clear implication to confer a right to contribution. Through the exercise of their power to craft federal common law, federal courts may also fashion a right to contribution." (internal citations omitted)). See also Bowers v. Nat'l Collegiate Athletic Ass'n, 346 F.3d 402, 425-26 (3d Cir. 2003) (citing Musick, 508 U.S. at 291) ("When a statute creates a private right of action but fails to provide expressly for a right to contribution, particularly if the remedial scheme created is detailed, Congress's silence with regard to contribution weights [sic] heavily against implying such a right because there is a presumption that the silence reflects congressional intent not to create such a right. On the other hand, when courts have implied a right of action it would be 'futile' to look for congressional intent to create a right to contribution, inasmuch as Congress did not intend explicitly to create the cause of action on which such a right would be based.").

97. See BUC Int'l Corp. v. Int'l Yacht Council Ltd., 517 F.3d 1271, 1276 (11th Cir. 2008) (citing Nw. Airlines, Inc. v. Transp. Workers Union of Am., 451 U.S. 77, 90-91 (1981) ("[T]he district court likened the attempt to claim credit for the settlements to a claim for contribution, which would only exist under the Copyright Act if either Congress created such a right, expressly or implicitly, or the courts created such a right as a matter of federal common law."); see also In re Dep't of Energy Stripper Well Exemption Litig., 968 F.2d 27, 34 (Temp. Emer. Ct. App. 1992) (explaining that in deciding whether restitution was available under the Economic Stabilization Act, "we have the clear guidance of the Supreme Court. In Northwest Airlines, Inc. v. Transport Workers Union, the Court concluded that a federal cause of action is created either through the affirmative creation of a right of action by Congress, either expressly or by clear implication, or, absent legislation, through the power of federal courts to fashion ... federal common law") (internal quotation marks and citations omitted)); Crescent Wharf \& Warehouse Co. v. Barracuda Tanker Corp., 696 F.2d 703, 705 (9th Cir. 1983). 
their liabilities, thus aligning it with Texas Industries and Northwest Airlines rather than with Musick. ${ }^{98}$ Therefore, to correctly determine whether ERISA allows contribution or indemnification, one must first look for congressional intent and then examine whether federal common law provides an avenue for their inclusion.

\section{Whether a Cause of Action Is Implicit-The Touche Test}

In Northwest Airlines, the Court pointed to cases such as Cort v. Ash as examples of analyses for courts to use to determine whether a cause of action exists. ${ }^{99}$ Cort $v$. Ash provided four factors to which it lent each equal weight: (1) congressional intent, (2) legislative history, (3) whether the remedies are "necessary to make effective the congressional purpose," 100 and (4) whether it is appropriate to limit the remedies to those supplied by state law. ${ }^{101}$ At the time, however, the Court was slowly formulating this analysis, and eventually settled on an analysis more akin to that set out in Touche Ross \& Co. v. Redington. ${ }^{102}$ These later cases still examined the factors but converted congressional intent into the determinative factor. ${ }^{103}$

In Touche, the Court explains this divergence:

It is true that in Cort v. Ash, the Court set forth four factors that it considered "relevant" in determining whether a private remedy is implicit in a statute not expressly providing one. But the Court did not decide that each of these factors is entitled to equal weight. The central inquiry remains whether Congress intended to create, either expressly or by implication, a private cause of action. Indeed, the first three factors discussed in Cort - the language and focus of the statute, its legislative history, and its purpose - are ones traditionally relied upon in determining legislative intent. ${ }^{104}$

In this way, the Court still ends up looking at the first three factors of Cort, albeit under the umbrella of "congressional intent."105 In fact, Touche modified the first factor from a general analysis of congressional

98. See 29 U.S.C. $\S \S 1109,1105(c), 1132$ (2012 \& Supp. V 2017).

99. Nw. Airlines, Inc. v. Transp. Workers Union of Am., 451 U.S. 77, 90 (1981).

100. Cort v. Ash, 422 U.S. 66, 80-84 (1975) (quoting J. I. Case Co. v. Borak, 377 U.S. 426, 433

(1964)), abrogation recognized by Ziglar v. Abbasi, 137 S. Ct. 1843 (2018)).

101. Id. at $84-85$.

102. 442 U.S. 560 (1979).

103. See Thompson v. Thompson, 484 U.S. 174, 188-89 (1988) (Scalia, J., concurring) (noting this trend and that Touche effectively overruled Cort v. Ash).

104. Touche, 442 U.S. at 575-76 (internal citations omitted).

105. See id. 
intent to a more focused look at the language of the statute for clues of congressional intent. ${ }^{106}$ As for the fourth factor, it seems the Court relegated it to almost a non-consideration. However, as with many federal specific statutes and with ERISA in particular which specifically preempts state law, ${ }^{107}$ this fourth factor would likely nonetheless be irrelevant, and it is perhaps where the discussion on federal common law more appropriately takes its place.

Therefore, courts analyzing whether cofiduciary contribution is implicitly found in ERISA should apply the more focused Touche test and determine congressional intent from the language of the statute, the legislative history, and whether the remedy furthers the purpose of the statute.

\section{a. Statutory Language}

In construing a statute, courts have several factors to consider. First, courts "are obliged to give effect, if possible, to every word Congress used." 108 Canons of construction typically provide that when dealing with disjunctive conjunctions like "or," courts ordinarily must assign separate meanings to the words separated by these conjunctions. ${ }^{109}$ In assigning these meanings, a court should not merely accept the broad dictionary definition of a word but rather choose one which fits "the specific context in which th[e] language is used, and the broader context of the statute as a whole." $" 110$ In fact, assuming the word is not already defined in the statute, its meaning should generally be one in accordance with what it ordinarily means. ${ }^{111}$ If the court determines that the statutory language is unambiguous - which is unlikely in a case like the current one, where the issue revolves around the ambiguity of the breadth of a statute - any further inquiry ceases. ${ }^{112}$ Otherwise, the court must then turn to legislative history. ${ }^{113}$ This analysis will be especially

106. Id. at 568 ("[A]s with any case involving the interpretation of a statute, our analysis must begin with the language of the statute itself.").

107. 29 U.S.C. $\S 1144($ a) (2012).

108. Reiter v. Sonotone Corp., 442 U.S. 330, 339 (1979) (citing United States v. Menasche, 348 U.S. 528, 538-39 (1955)).

109. Id.; see also FCC v. Pacifica Found., 438 U.S. 726, 739-40 (1978).

110. Yates v. United States, 135 S. Ct. 1074, 1081-82 (2015) (citing Robinson v. Shell Oil Co., 519 U.S. 337, 341 (1997); see also Epic Sys. Corp. v. Lewis, 138 S. Ct. 1612, 1631 (2018).

111. Sebelius v. Cloer, 569 U.S. 369, 376 (2013) (explaining that applying how a term is commonly understood is also applying the ordinary meaning).

112. Kingdomware Techs., Inc. v. United States, 136 S. Ct. 1969, 1976 (2016) (quoting Barnhart v. Sigmon Coal Co., 534 U.S. 438, 450 (2002)).

113. See Yates, 135 S. Ct. at 1084 (turning to analyze legislative history after being unable to 
important when determining the meaning of "equitable relief" within ERISA.

\section{b. Legislative History}

Admittedly, the Supreme Court's inclusion of the legislative history as one of the factors to consider when interpreting a statute came during a time prior to the late Justice Scalia's ardent crusade against the use of such history in statutory interpretation. ${ }^{114}$ However, a dismissal of legislative history when dealing with an ERISA issue, especially one in which the arguments for the inclusion of a remedy rely so heavily on federal common law, would be a grievous injustice. ERISA's legislative history explicitly blesses the development of its federal common law. ${ }^{115}$ Thus, applying what the courts would have known at the time of ERISA's birth regarding legislative history establishes some guidelines.

"[F]requently[,] the legislative history of a statute is the most fruitful source of instruction as to its proper interpretation ...."116 However, one must be cautious in such reliance. ${ }^{117}$ Often times, legislative history may be silent on an ambiguity. In the case of an implied right of action, interpreting the silence as an authorization for the private right has been described as a "hazardous enterprise." ${ }^{118}$ After all, silence can lead to

determine the meaning of words from the language alone).

114. See, e.g., Elizabeth A. Liess, Comment, Censoring Legislative History: Justice Scalia on the Use of Legislative History in Statutory Interpretation, 72 NEB. L. REV. 568, 568-69 (1993).

115. See H.R. REP. NO. 101-247, at 55-56 (1989). In addressing the issue, Professor George L. Flint explained:

The House Budget Committee had received numerous complaints from constituents that Pilot Life Ins. Co. v. Dedeaux left them with no legal remedy for improper denials of medical claims, improper denial of continuation coverage, or unreasonable delays in processing claims. The Committee disagreed with that portion of Pilot Life refusing to develop a common law remedy, but felt it was not necessary to amend ERISA. The Committee felt that the legislative history of ERISA clearly indicated that Congress intended courts, through federal common law, to develop "appropriate remedies, even if they are not specifically enumerated in section 502 of ERISA," for improper claims processing. The Committee reaffirmed the "authority of the Federal courts to shape legal and equitable remedies to fit the facts and circumstances of the cases before them, even though those remedies may not be specifically mentioned in ERISA," by "drawing upon principles enunciated in state law, including such remedies as the awarding of punitive and/or compensatory damages against the person responsible for the failure to pay claims in a timely manner."

George L. Flint, Jr., ERISA: Reformulating the Federal Common Law for Plan Interpretation, 32 SAN Diego L. ReV. 955, 964 n.44 (1995) (quoting H.R. ReP. NO. 101-247, at 55-56) (internal citations omitted); see also id. at 970-73 (discussing the federal common law of ERISA).

116. Flora v. United States, 362 U.S. 145, 151 (1960).

117. Piper v. Chris-Craft Indus., 430 U.S. 1, 26 (1977).

118. Touche Ross \& Co. v. Redington, 442 U.S. 560, 571 (1979). 
two competing inferences, one in favor of the implication and one against. ${ }^{119}$ Additionally, just because the legislative history contains examples illustrating certain points, it does not mean that the entirety of the statute is limited to them-examples are "just that," examples, and are not meant to be exhaustive. ${ }^{120}$ Finally, as always, courts must remember to read the legislative history objectively and not "interpolat[e] [their] notions of policy in the interstices of legislative provisions." 121

c. Purpose

The "purpose" factor of the Touche test refers to whether the implied remedy is "consistent with the underlying purposes of the legislative scheme." 122 To ascertain purpose, the courts are left with examining the legislative scheme. It seems that such a directive is nothing more than a repeat of the second factor, although it may arguably leave room for a broader interpretation of legislative history. Fortunately for ERISA practitioners, ERISA's purpose is found in 29 U.S.C. $\S 1001$. Conveniently labeled "Congressional findings and declaration of policy," this section provides a starting place for courts to determine the purpose against which they must compare the requested implied remedy. ${ }^{123}$ The section provides that Congress's general goal in enacting the statute is to promote the interests of employees and their beneficiaries by regulating the creation and administration of employee benefit plans. ${ }^{124}$ Such regulations and administrative requirements are meant to ensure the "soundness and stability of plans" so that they may be well-funded and able to pay out any promised benefits. ${ }^{125}$

Given that Touche has been precedent since the circuit split on cofiduciary contribution and indemnification in ERISA began, it is worthwhile to wonder why the circuit courts have not used its analysis. Except for the Second Circuit, no court explicitly stated why it did not use Touche, or a similar test, in coming to its conclusion. This Comment will discuss some possible reasons later, but it will first address the

119. See, e.g., Pension Benefit Guar. Corp. v. LTV Corp., 496 U.S. 633, 650 (1990) (noting that a lack of congressional action can create "several equally tenable inferences" (quoting United States v. Wise, 370 U.S. 405, 411 (1962))).

120. Id. at 649 .

121. Piper, 430 U.S. at 26 (quoting Scripps-Howard Radio, Inc. v. FCC, 316 U.S. 4,11 (1942)).

122. Cort v. Ash, 422 U.S. 66, 78 (1975).

123. 29 U.S.C. $§ 1001$ (2012).

124. See generally id.

125. Id. § 1001(a). 
second way in which a claim for contribution may arise-via federal common law.

\section{Whether Courts May Fashion ERISA Common Law}

Most courts that have allowed remedies for contribution and indemnification in ERISA do so under the guise that they have the power as developers of the federal common law. ${ }^{126}$ While, generally, "[t]here is ... 'no federal general common law,' ... the Court has recognized the need and authority in some limited areas to formulate what has come to be known as "federal common law." "127 One of these areas is ERISA. ${ }^{128}$ As a tool to help lower courts develop the common law, the Court pointed to the principles of trust law. ${ }^{129}$ These principles, it held, should apply to ERISA fiduciaries. ${ }^{130}$

To what extent courts may use their authority to develop federal common law for ERISA depends largely on the philosophy of the court. Some have limited themselves from expanding the law, while others have not. ${ }^{131}$ Perhaps a reason for this is that the Court has never addressed when it is appropriate to create such law, instead limiting itself to deciding when it is not appropriate to do so. For example, in Varity Corp. v. Howe, the Court noted that trust law principles are not necessarily determinative of ERISA common law. ${ }^{132}$ In fact, when applying trust law to ERISA, the Court has warned lower courts to take note of "competing congressional purposes"-arguably favoring a holding in line with a finding of congressional intent over a holding in

126. See, e.g., Chemung Canal Tr. Co., 939 F.2d 12, 18 (2d Cir. 1991) (holding that "incorporating traditional trust law's doctrine of contribution and indemnity into the law of ERISA is appropriate..." because "[C]ongress wanted courts to fill any gaps in the statute by looking to traditional trust law principles."); Chesemore v. Fenkell, 829 F.3d 803, 807 (7th Cir. 2016) (noting that ERISA “doesn't specifically mention contribution or indemnity as a remedy. Instead, it broadly permits the court to fashion 'appropriate equitable relief"').

127. Tex. Indus., Inc. v. Radcliff Materials, Inc., 451 U.S. 630, 640 (1981) (quoting Erie R. Co. v. Tompkins, 304 U.S. 64, 78 (1938) \& U.S. v. Standard Oil Co., 332 U.S. 301, 308 (1947)).

128. See Firestone Tire \& Rubber Co. v. Bruch, 489 U.S. 101, 110 (1989) ("Given this language and history, we have held that courts are to develop a 'federal common law of rights and obligations under ERISA-regulated plans."” (quoting Pilot Life Ins. Co. v. Dedeaux, 481 U.S. 41, 56 (1987))).

129. See id. at 111 (discussing trust principles relating to standards of review of a trustee's exercise of discretionary powers so as to apply them to ERISA).

130. Id. ("In determining the appropriate standard of review for actions under $\S 1132(\mathrm{a})(1)(\mathrm{B})$, we are guided by principles of trust law.").

131. See Jeffrey A. Brauch, The Federal Common Law of ERISA, 21 HARV. J.L. \& PUB. POL'Y 541, 544-45 (1998) (comparing instances where courts have and have not created federal common law).

132. 516 U.S. 489, 497 (1996) ("[W]e believe that the law of trusts often will inform, but will not necessarily determine the outcome of, an effort to interpret ERISA's fiduciary duties."). 
line with a trust principle. ${ }^{133}$ As for remedies, the Supreme Court has also stated that courts should consider ERISA's carefully integrated scheme as "strong evidence that Congress did not intend to authorize other remedies that it simply forgot to incorporate expressly." 134

Thus, the Supreme Court has provided lower courts with more warnings and less direction about when it is appropriate to develop federal common law. Lower courts have been left largely to their own devices to determine when a case is appropriate for the development of ERISA's federal common law. Some authors have been highly critical of this development, accusing "lawyers representing plan administrators [to] have seriously undermined congressional intent by misapplying the doctrine of federal common law." 135

Nonetheless, it is true that lower courts generally tend to be more apprehensive when the statute expressly covers an issue, so as to not "allow federal common law to rewrite ERISA's carefully crafted statutory scheme."136 Some circuits have limited this law making authority to situations in which it is necessary to "fill in interstitially or otherwise effectuate [ERISA's] statutory pattern and purpose enacted ... by Congress." 137 Only the Sixth Circuit has provided factors to determine when it is appropriate for the courts to fashion federal law. In doing so, it has granted itself more latitude by considering "instances in which (1) ERISA is silent or ambiguous; (2) there is an awkward gap in the statutory scheme; or (3) federal common law is essential to the promotion of fundamental ERISA policies." 138 The Sixth Circuit does not limit itself to develop common law only when it furthers a

133. Id. (" $[\mathrm{C}]$ ourts may have to take account of competing congressional purposes, such as Congress' [s] desire to offer employees enhanced protection for their benefits, on the one hand, and, on the other, its desire not to create a system that is so complex that administrative costs, or litigation expenses, unduly discourage employers from offering welfare benefit plans in the first place."); see also Mertens v. Hewitt Assocs., 508 U.S. 248, 261-63 (1993) (criticizing "vague notions of a statute's "basic purpose," but then explaining that in the particular issue at hand (third-party nonfiduciary liability), Congress's attempt at and goal of balancing two competing interests"tension between the primary [ERISA] goal of benefitting employees and the subsidiary goal of containing pension costs" - overrides traditional trust law, which allowed for beneficiaries to recover from third parties for knowing participation in a trustee's breach as non-fiduciaries).

134. Mass. Mut. Life Ins. Co. v. Russell, 473 U.S. 134, 146 (1985).

135. Flint, supra note 115, at 959.

136. State St. Bank \& Tr. v. Denman Tire Corp., 240 F.3d 83, 89 (1st Cir. 2001).

137. See Van Ormna v. Am. Ins., 680 F.2d 301, 312 (3d Cir. 1982) (quoting United States v. Little Lake Misere Land Co., 412 U.S. 580, 593 (1973)); see also id. at 89 (discussing the development of restitution plan that compliments ERISA's purpose).

138. DiGeronimo Aggregates, LLC v. Zemla, 763 F.3d 506, 511 (6th Cir. 2014) (citing Local 60682 Int'l Union of Paper, Allied-Indus. Chem. \& Energy Workers v. Nat'l Indus. Grp. Pension Plan, 342 F.3d 606, 609 (6th Cir. 2003)). 
fundamental ERISA purpose, but it also allows itself this ability when ERISA is silent or there is an "awkward gap." As a result, the Sixth Circuit is more progressive, as other commentators have limited this rulemaking authority to instances where the created rule "further[s] the policy of the statute." 139

A court's decision on whether to develop federal common law likely comes down to the decision maker's philosophy on the extent of judicial involvement in lawmaking. ${ }^{140}$ This Comment, however, will not discuss the arguments for or against the more conservative or the more liberal view. Instead, this Comment strives to show that under the more conservative view, one cannot create a remedy of cofiduciary contribution under federal common law, and that under the more liberal view, courts should refrain from doing so by keeping in mind the Supreme Court's caution in creating new remedies.

\section{ANALYSIS}

As previously explained, in situations where the remedial provisions of a statute are expressly provided, the proper analysis to determine an implicit right to contribution and indemnification must examine two areas: (1) acts of Congress, be they express or implicit; and (2) if necessary, the power of federal courts to fashion the statute's federal common law. ${ }^{141}$

This Section applies that test to determine whether cofiduciary contribution or indemnification are implicit in ERISA, and, finding that they are not, argues against creating them through federal common law. In determining that cofiduciary contribution is not implicit in ERISA, this Comment applies the Touche test. The Second Circuit argues against the application of the test, but after determining that cofiduciary contribution and indemnification are rights of action rather than procedural devices, there is no reason not to apply the structured analysis of Touche, especially when the Supreme Court called for such an analysis when it established the steps for finding contribution as an

139. Flint, supra note 115, at 969.

140. Compare Brauch, supra note 131, at 563-71 (arguing for limited involvement out of respect for the separation of powers and the threat of inconsistent laws and regulations), with William $\mathrm{K}$. Carr \& Robert L. Liebross, Wrongs Without Rights: The Need for a Strong Federal Common Law of ERISA, 4 STAN. L. \& POL'Y REV. 221, 222-23 (1993) (arguing that courts have shied away from using their authority to apply traditional principles of equity, but instead should rely on "timehonored principles of ... common law").

141. Tex. Indus., Inc. v. Radcliff Materials, Inc., 451 U.S. 630, 638 (1981) (citing Nw. Airlines, Inc. v. Transp. Workers, 451 U.S. 77, 90-91 (1980)). 
implicit remedy. ${ }^{142}$

\section{A. An Implicit Reading of Contribution and Indemnification Remedies Into ERISA}

1. Should Touche Apply?

Four circuit courts have examined cofiduciary contribution and indemnification. ${ }^{143}$ None of them have expressly mentioned Touche or its test. This begs the question of whether the Touche test is inappropriate. The four circuit courts focused on federal common law and almost completely disregarded whether such a cause of action may be implied under a congressional intent analysis. Only the Second Circuit attempted to dismiss the test as inappropriate, and even then, it was referring to the test as originally articulated in Cort v. Ash. ${ }^{144}$

For example, the Eighth Circuit limited its review to whether "the 'federal common law of rights and obligations under ERISA-regulated plans' should provide that an ERISA fiduciary found liable for violating its obligations under the statute may bring an action for contribution against another fiduciary that allegedly bears some responsibility for the violations." $" 145$ The Eighth Circuit thus did not even consider congressional intent outside of the federal common law analysis. ${ }^{146}$ The Ninth Circuit, for its part, did little to differentiate between a federal common law analysis and a congressional intent analysis in the woefully insufficient two paragraphs it designated to discussing the issue. ${ }^{147}$ Alternatively, the Seventh Circuit did engage in a bit more detailed statutory interpretation in determining that the "equitable relief" in ERISA $\S 502(a)(3)$ includes contribution and indemnification. ${ }^{148}$ It made this determination in the context of defining the breadth of its remedial authority under the statute. ${ }^{149}$ Thus, while it did not explicitly state whether it applied any particular analysis, the court effectively employed

142. Nw. Airlines, Inc. v. Transp. Workers Union, 451 U.S. 77, 90 (1981).

143. See generally Travelers Cas. \& Sur. Co. of Am. v. IADA Servs., Inc., 497 F.3d 862 (8th Cir. 2007); Kim v. Fujikawa, 871 F.2d 1427 (9th Cir. 1989); Chesemore v. Fenkell, 829 F.3d 803 (7th Cir. 2016); Chemung Canal Tr. Co. v. Sovran Bank/Md., 939 F.2d 12 (2d Cir. 1991).

144. Chemung, 939 F.2d at 15-16 ("Initially, we agree with Sovran that the Cort v. Ash methodology is an inappropriate tool for analyzing this case.").

145. Travelers, 497 F.3d at 864 (citing Pilot Life Ins. Co. v. Dedeaux, 481 U.S. 41, 56 (1987)) (internal citations omitted).

146. Id.

147. Kim, 871 F.2d at $1432-33$.

148. Chesemore, 829 F.3d at $811-13$.

149. Id. at 812 . 
an analysis on whether the remedies were implicit in the statute.

Interestingly, the Second Circuit explicitly chose not to apply the four-part Cort v. Ash test. The court considered the test "too simplistic" because it determined that contribution was a "procedural device" rather than a "right of action," and thus absolved itself of applying the test. ${ }^{150}$ Instead, the Second Circuit limited its discussion of congressional intent by citing to case law that observed ERISA's legislative history and the court's authority to draw on principles of traditional trust law for the development of ERISA common law. ${ }^{151}$

The Eighth and Ninth Circuits did not explain why they skipped any congressional intent analysis in declining to find a remedy for cofiduciary contribution. It is possible that because the statute is silent as to contribution or indemnification, the courts chose to forego the analysis of whether the remedies can be implied and instead focused their analysis entirely on whether their authority allowed them to create the common law remedies. The Second Circuit, however, raised an argument that threatens the premise of this Comment: are contribution and indemnification procedural devices rather than causes of action and thus exempt from the Touche test? The answer is a resounding no.

The Second Circuit described contribution as a means of "allocating obligations among co-defendants and/or third parties," and it is perhaps this distinction that nudged the court to consider contribution as a procedural device. ${ }^{152}$ Seventeen years after Chemung, a Connecticut district court attempted to provide more insight on this notion in Haddock v. Nationwide Financial Services, Inc. ${ }^{153}$ The district court first stated that "the right to seek contribution and indemnification ... is a procedural device, implicit in the common law of trusts, for fairly distributing costs among all culpable parties regardless of whom the plaintiff chooses to sue directly."154 The court then argued that allowing such a right is not the creation of an additional remedy, but rather the extension of the principles of the law of trusts into the federal common law of ERISA. ${ }^{155}$ The court, however, failed to explain why contribution

150. Chemung, 939 F.2d at 16 ("The four tests of Cort v. Ash are not well-designed to ferret out congressional intent at this level of dispute resolution.").

151. See id. (discussing Firestone Tire \& Rubber Co. v. Bruch, 489 U.S. 101, 110 (1989); Donovan v. Bierwirth, 754 F.2d 1049, 1055 (2d Cir. 1985); Eaves v. Penn, 587 F.2d 453, 462-63 (10th Cir. 1978)).

152. Id. at 15 .

153. Haddock v. Nationwide Fin. Servs., Inc., 570 F. Supp. 2d 355, 358-61 (D. Conn. 2008).

154. Id. at 360 .

155. $I d$. 
and indemnification are procedural devices rather than remedies under the law of trusts. ${ }^{156}$ Furthermore, classifying contribution and indemnification as procedural devices then runs contrary to Seventh Circuit's holding, in which cofiduciary contribution and indemnification were allowed as equitable remedies grounded in the law of trusts. ${ }^{157}$

Such an assertion is simply not correct. First, there is a distinction between contribution itself and the procedural device of impleader, which is used to join defendants to be able to more efficiently carry on suits. ${ }^{158}$ Impleader is "almost always" used to bring suits for contribution and allows for "efficient litigation by packaging the underlying claim ... and any indemnity or contribution claims in a single case."159 Rule 14(c)(1) is the only Federal Rule of Civil Procedure that addresses contribution in the limited scope of admiralty law, and even there it is referred to as a remedy. ${ }^{160}$ In fact, in Bogert's Trusts and Trustees, which the Second Circuit cites to in Chemung, ${ }^{161}$ Bogert expressly denotes inter-fiduciary contribution as a cause of action and makes no reference to any procedural device distinction. ${ }^{162}$ Finally, while different from trust law, under tort law the Supreme Court has held the rights of contribution and indemnification for tortfeasors who are statutorily jointly liable as independent causes of action. ${ }^{163}$ For these reasons, the courts cannot rely on the implementation of contribution as a procedural device, but must rather examine whether contribution and indemnification are implied private rights of action under ERISA. To do so, they should first apply the Touche test.

156. Id.

157. Chesemore v. Fenkell, 829 F.3d 803, 811-12 (7th Cir. 2016).

158. 3 James WM. Moore et AL., Moore’s Federal Practice $§ 14.03(1)$ (3d ed. 2019).

159. Id.

160. FED. R. CIV. P. 14(c)(1) ("If a plaintiff asserts an admiralty or maritime claim under Rule 9(h), the defendant or a person who asserts a right under Supplemental Rule C(6)(a)(i) may, as a third-party plaintiff, bring in a third-party defendant who may be wholly or partly liable - either to the plaintiff or to the third-party plaintiff-for remedy over, contribution, or otherwise on account of the same transaction, occurrence, or series of transactions or occurrences.") (emphasis added).

161. Chemung Canal Tr. Co. v. Sovran Bank/MD, 939 F.2d 12, 16 (2d Cir. 1991).

162. George G. Bogert et Al., Bogert's Trust And Trustees $§ 701$ (2019) (“The trustee who is obliged to pay more than his or her proportionate share of the damage may have a cause of action for contribution against the co-trustees who are equally or more guilty.").

163. Musick, Peeler \& Garrett v. Emp'rs Ins. of Wausau, 508 U.S. 286, 291-92 (1993). 


\section{The Touche Test}

a. The Language and Focus of the Statute

As the Touche Court stressed: "[W]ith any case involving the interpretation of a statute, [the] analysis must begin with the language of the statute itself." 164 In addition to the language of the statute, courts should also examine the statutory scheme. ${ }^{165}$ Keeping this in mind, we turn to the provisions at the center of debate: ERISA $\S 409$ (29 U.S.C. $\S$ 1109) and ERISA § 502(a)(2)-(3) (29 U.S.C. § 1132(a)(2)-(3)).

i. $\quad$ ERISA $\S 409(a)$

ERISA $\S 409$ (a) states:

Any person who is a fiduciary with respect to a plan who breaches any of the responsibilities, obligations, or duties imposed upon fiduciaries by this subchapter shall be personally liable to make good to such plan any losses to the plan resulting from each such breach, and to restore to such plan any profits of such fiduciary which have been made through use of assets of the plan by the fiduciary, and shall be subject to such other equitable or remedial relief as the court may deem appropriate, including removal of such fiduciary. A fiduciary may also be removed for a violation of section 1111 of this title. ${ }^{166}$

The plain language of $\S 409$ (a) provides three ways in which a breaching fiduciary may remedy its breach: (1) by "mak[ing] good to such plan any losses to the plan resulting from the breach;" (2) by restoring to the plan any profits earned by the fiduciary via prohibited use of the assets; and (3) through such other equitable or remedial relief as the court "may deem appropriate." 167 The first two very plainly state that the plan is the beneficiary of the relief. The third, however, is ambiguous.

To discover the meaning of the third form of relief, we must "give effect, if possible, to every word Congress used." 168 Let us assume for this section that "equitable relief" includes contribution and

\footnotetext{
164. Touche Ross \& Co. v. Redington, 442 U.S. 560, 568 (1979) (citing Cannon v. Univ. of Chi., 441 U.S. 677,689 (1979)).

165. See id. at 571-72 (examining statutory scheme to support decision not to imply a private remedy).

166. 29 U.S.C. $§ 1109$ (a) (2012).

167. Id.

168.Reiter v. Sonotone Corp., 442 U.S. 330, 339 (1979).
} 
indemnification. Note the conjunction used to combine the three remedies is not disjunctive; therefore, this is a good indication that the remedies allotted in the third part should relate to the first two remedies rather than be one with a completely different meaning. ${ }^{169}$

We then look at the context in which this phrase is being used. ${ }^{170}$ The phrase follows two other remedies, both of which are directed towards the plan alone. Further, these first two remedies are legal remedies-monetary damages for losses suffered as a result of the breach, or the actual losses plus any lost gains. Therefore, we can infer that Congress intended this third to be for the benefit of the plan and to add equitable remedies to the plan's arsenal in addition to the aforementioned legal remedies. Finally, the example provided in the statute, although not by any means exhaustive, offers relief to the plan by removing the fiduciary from its administration. This also adds credence to the inference that Congress intended the remedies to be for the benefit of the plan alone. Cofiduciary contribution and indemnification should therefore not be found in ERISA $\S$ 409(a). The Supreme Court employed a similar analysis in Massachusetts Mutual Insurance Co. v. Russell when it came to the same conclusion for a different remedy. ${ }^{171}$

ii. ERISA $\S 502(a)$ and (3)

ERISA $\S 502$ (a) begins with the words, "A civil action may be brought," and then splits the possible plaintiffs into numbered paragraphs. The paragraphs relevant to this discussion due to their affording of causes of action to fiduciaries are (2) and (3). ${ }^{172}$

ERISA § 502(a)(2) states, "by the Secretary, or by a participant, beneficiary or fiduciary for appropriate relief under section 1109 of this title." 173 This section allows the participants, beneficiaries, or fiduciaries to bring an action to recover the relief available under ERISA $\S 409 .{ }^{174}$

\footnotetext{
169. See id. ("Canons of construction ordinarily suggest that terms connected by a disjunctive be given separate meanings ...."). While the analysis in Reiter was aimed towards words joined by disjunctive conjunctions, it would seem appropriate to extend such a concept to phrases as well.

170. See Yates v. United States, 135 S. Ct. 1074, 1081-82 (2015) (“'[T]he plainness or ambiguity of statutory language is determined [not only] by reference to the language itself, [but as well by] the specific context in which that language is used, and the broader context of the statute as a whole." (quoting Robinson v. Shell Oil Co., 519 U.S. 337, 341 (1997))); see also Epic Sys. Corp. v. Lewis, 138 S. Ct. 1612, 1631 (2018) (stating that "[1]inguistic and statutory context also matter" when determining a statute's meaning).

171. 473 U.S. 134, 139-44 (1985).

172. 29 U.S.C. $\S 1132(2012)$.

173. Id. § 1132(a)(2).

174. Id.
} 
Because this relief is only available to the plan, ${ }^{175}$ we can infer that ERISA $\S 502(a)(2)$ only allows individuals to bring actions for the benefit of the plan. The Supreme Court also reached this conclusion in Russell. ${ }^{176}$

ERISA $\S 502(\mathrm{a})(3)$ proves more problematic. It states:

[B]y a participant, beneficiary, or fiduciary (A) to enjoin any act or practice which violates any provision of this title or the terms of the plan, or (B) to obtain other appropriate equitable relief (i) to redress such violations or (ii) to enforce any provisions of this subchapter or the terms of the plan. ${ }^{177}$

Subparagraph (B) provides the strongest avenue for an argument in favor of cofiduciary contribution and indemnification. It opens the question as to whether "other appropriate equitable relief" can include contribution and indemnification. After looking at the definition of "equitable remedy," one could suggest it does.

Black's Law Dictionary defines "Equitable Remedy" as "a remedy, usually a nonmonetary one such as an injunction or specific performance, obtained when available legal remedies, usually monetary damages, cannot adequately redress the injury. Historically, an equitable remedy was available only from a court of equity." 178 In CIGNA Corp. v. Amara, the Supreme Court used a similar definition, explaining that "appropriate equitable relief" here means "those categories of relief that, traditionally speaking (i.e., prior to the merger of law and equity) were typically available in equity." 179

Traditionally, equity had exclusive jurisdiction over trust law because "the common law recognizes no action for breach of trust.". By the mid-nineteenth century, the Chancery courts had extended contribution to traditional trust law and "recognized indemnity without an agreement." 181 The United States courts followed in this development, establishing that contribution and indemnity were first equitable remedies. ${ }^{182}$ Therefore, the plain language of the statute

\footnotetext{
175. See supra Section III.A.2.a.i.

176. Russell, 473 U.S. at 144.

177. 29 U.S.C. $\$ 1132$ (a)(3) (2012).

178. Equitable Remedy, BLACK's LAW Dictionary (10th ed. 2014).

179. CIGNA Corp. v. Amara, 563 U.S. 421, 439 (2011) (quoting Sereboff v. Mid Atl. Med. Servs., 547 U.S. at 356, 361 (2006)) (internal quotation marks and citations omitted).

180. Flint, supra note 10, at n.37 (internal quotation marks and citations omitted).

181. Id. at 11 .

182. Id.
} 
arguably contemplates that equitable relief includes contribution and indemnification.

But the analysis does not end there. We must also examine the rest of the subsection. The statute limits this equitable relief to that which is appropriate to redress violations of any subchapter of ERISA or terms of the plan. ${ }^{183}$ While claims for contribution tend to occur simultaneously with the underlying issue, claims for contribution are independent and occur when the defendant seeks contribution from other guilty parties for the amount for which it has been found liable. ${ }^{184}$ Given that each guilty cofiduciary is jointly and severally liable, ${ }^{185}$ the relief available for the plan and its beneficiaries is not reduced or affected by whether contribution or indemnification exist. Contribution and indemnification are thus there only for the benefit of the fiduciaries and play no role in whether the plan or its beneficiaries are properly remedied. Although contribution and indemnification do not affect the proper compensation of the plan or its beneficiaries, such relief is arguably nonetheless an "appropriate" means for the guilty parties to go about redressing the violations. After all, the adjective in the statute is not "necessary."186

According to Webster's Seventh New Collegiate Dictionary, "appropriate" means "especially suitable or compatible; [fitting]."187 Because contribution and indemnification do not affect the ultimate payout received by the plan or beneficiaries, perhaps such remedies are compatible with ERISA in a suit by a fiduciary against another for the purpose of redressing a violation. Furthermore, ERISA $\S 502(\mathrm{a})(3)(\mathrm{A})$ and (B)(ii) cover two other forms of equitable relief: injunction and specific performance. The separation of the clauses from subsection (B)(i) by a disjunctive conjunction would suggest we attempt to provide a distinction to the equitable relief available under subsection (B)(i). ${ }^{188}$ But even "appropriate relief" is limited to redressing violations. ${ }^{189}$ Furthermore, implying such a benefit to breaching fiduciaries who are the very parties that ERISA sought to regulate seems inconsistent with the general purpose of the statute which is so focused on the

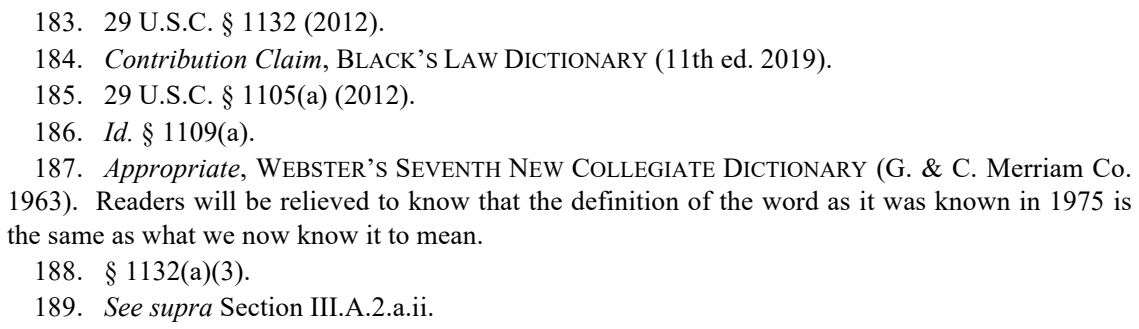


beneficiaries. A plain reading of the statute would thus not imply cofiduciary contribution or indemnification. At the very best one could argue that the statute is ambiguous. But even if ambiguous, the legislative history does not support the creation of such a remedy.

\section{b. Legislative History}

The Court has seen ERISA's structural scheme and complexity as evidence that Congress specifically did not intend to imply remedies that it "simply forgot" to include. ${ }^{190}$ Given the time Congress took to craft such a complex remedial structure, it is unlikely that Congress forgot to incorporate the remedies in question. ${ }^{191}$ By looking at the legislative history, however, it becomes very clear that cofiduciary contribution or indemnification were nowhere near the forefront of Congress's mind. While this does not show that Congress did not intend to include the remedies, it does not favor their creation either. However, the development of ERISA throughout its different incarnations seems to suggest that Congress did not intend to implicitly authorize the inclusion of the equitable remedies of contribution and indemnification for the benefit of cofiduciaries.

Congress originally intended to regulate retirement benefits, particularly pensions, with the Welfare and Pension Plans Disclosure Act (WPPDA) in $1958 .{ }^{192}$ Congress then amended the WPPDA in 1962 to, in part, confer "investigatory and various regulatory powers upon the Secretary over pension and welfare funds." 193 However, all the WPPDA required was disclosure, but the information disclosed was minimal. ${ }^{194}$ The WPPDA also failed to sufficiently outline the duties of fiduciaries to the plan, and many plans fell prey to their mismanagement. ${ }^{195}$ Congress thus proposed to amend the current law with a new bill, albeit still in gestation, which along with a plethora of other things, "in essence, codifies and makes applicable to these fiduciaries certain principles

190. See Mass. Mut. Life Ins. Co. v. Russell, 473 U.S. 134, 146 (1985) (stating that "Congress did not intend to authorize other remedies that it simply forgot to incorporate expressly.").

191. See id. ("The assumption of inadvertent omission is rendered especially suspect upon close consideration of ERISA's interlocking, interrelated, and interdependent remedial scheme, which is in turn part of a comprehensive and reticulated statute." (internal quotation marks omitted) (citing Nachman Corp. v. Pension Benefit Guar. Corp., 446 U.S. 359, 361 (1980))).

192. Welfare and Pension Plans Disclosure Act of 1958, Pub. L. No. 85-836, 72 Stat. 997 (1985) repealed by Employment Retirement Income Security Act of 1971, 29 U.S.C. § 1031(a) (2012).

193. S. REP. NO. 93-127, at 4840 (1973), 1973 WL 12550.

194. Id. at 4863.

195. See id. at 4865 (noting that without more defined fiduciary responsibilities, state trust laws had caused courts to allow deviations from plans). 
developed in the evolution of the law of trusts."196 This general principle is usually extended as evidence to show that cofiduciary contribution and indemnification should likewise be allowed. ${ }^{197}$

However, note the qualifier, "certain." The Senate noted that many plans were "structured in such a way that it [was] unclear whether the traditional law of trusts [was] applicable." 198 Many plans were formed and funded under insurance principles and placed only minimal restrictions on its administration. ${ }^{199}$ Additionally, even when plans relied on trust law, trust law allowed certain exemptions from liability for trustees who deviated from what we now consider their fiduciary duty. ${ }^{200}$ These exemptions, while allowed in scenarios when the trustee could be following the instructions of the settlor, were simply inapplicable in an employee benefit plan covering thousands of participants. ${ }^{201}$ Further, by providing standards with which to measure fiduciary conduct, Congress hoped to equip participants with safeguards to protect their own rights and plan assets. ${ }^{202}$ Thus, the Senate hoped to give participants the full weight of any rights they could have under trust law. Fiduciaries, instead, would look to trust law for their duties. ${ }^{203}$

Congress discussed the applicability of trust law to fiduciary responsibilities by pointing out the proposed modifications to then section 15(a), (b), and (c) of the WPPDA ${ }^{204}$ where it incorporated the "core principles of fiduciary conduct as adopted from existing trust law."205 Congress explained that sections 15(d) and (e) codified rules from the law of trusts that make fiduciaries personally liable, but again it

196. Id.

197. See, e.g., Travelers Cas. \& Sur. Co. of Am. v. IADA Servs., 497 F.3d 862, 864-65 (8th Cir. 2007); Chesemore v. Fenkell, 829 F.3d 803, 811-812 (7th Cir. 2016) (discussing that ERISA's grant of equitable remedy power to the courts allows the courts to order indemnification or contribution).

198. S. REP. NO. 93-127, at 4865 (1973), 1973 WL 12550.

199. Id.

200. Id.

201. Id.

202. Id.

203. Id. at 4871 ("The enforcement provisions have been designed specifically to provide both the Secretary and participants and beneficiaries with broad remedies for redressing or preventing violations of the Retirement Income Security for Employees Act as well as the amendments made to the Welfare and Pension Plans Disclosure Act. The intent of the Committee is to provide the full range of legal and equitable remedies available in both state and federal courts and to remove jurisdictional and procedural obstacles which in the past appear to have hampered effective enforcement of fiduciary responsibilities under state law or recovery of benefits due to participants.").

204. Compare S. 4, 93d Cong. § 510 (1973), with 29 U.S.C. § 1104 (2012).

205. S. REP. NO. 93-127, at 4866 (1973), 1973 WL 12550. 
did not discuss remedies amongst cofiduciaries. ${ }^{206}$

In the thousands of pages of legislative history spanning the four to five years it took to draft ERISA, I have only been able to find one reference that may possibly be taken to apply general trust principles to remedies. In House Conference Report No. 93-1280, one month before the enactment of ERISA, the report succinctly states: "In addition, the general rules of co-fiduciary liability are to apply."207 Alone, perhaps this statement encompasses the remedies of contribution or indemnification, but that sentence is nestled in a paragraph explaining how a trustee becomes liable for the acts of another trustee, notwithstanding the allocation of duties, for failing to comply with other fiduciary standards such as the prudent man standard-the standard which as we have seen above is one of the specific things the courts have a directive to interpret. ${ }^{208}$ Again, Congress seems more concerned with duties and liability than with remedies.

An examination of the development of the remedial sections of ERISA also suggests that Congress not only failed to consider contribution and indemnification but also did not intend to implicitly authorize them. In 1968, the new and improved remedies still focused on awarding participants and beneficiaries penalties for the failure of their plan administrator to provide them with certain documentation, but also introduced the ability for beneficiaries and participants to recover damages for the fiduciary's breach of their fiduciary duty, to enjoin the fiduciary, and to remove the fiduciary. ${ }^{209}$ If any trust law applied, it was the following:

[B]asically ... the elementary trust law doctrine that if a trustee loses trust property by his wrongdoing or fails to perform any of the duties placed upon him and causes thereby a loss to the trust funds, the beneficiary is entitled to compel the trustee to restore the trust property or to pay into the fund the amount of damages suffered. ${ }^{210}$

Yet, this application was to section $14(\mathrm{~g})$ and $(\mathrm{j})$, the sections on fiduciary liability and the voiding of any exculpatory agreementsubsections (i) and (j) of section 9 were added simply to facilitate the enforcement of those new sections. ${ }^{211}$

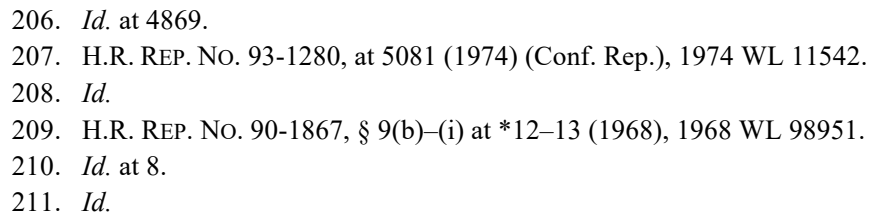


By 1970, the enforcement action had taken the wording with which we are more familiar now, but notably lacked any reference to a civil cause of action for fiduciaries. ${ }^{212}$ The relief was limited in favor of beneficiaries or participants alone in section $9(\mathrm{e})(1)$, or as a class in section 9(e)(2), and to the Secretary in section 9(e)(3). ${ }^{213}$ Although the structure changed slightly, the remedies stayed the same in the House's January $1971^{214}$ and December $1971^{215}$ versions and in the Senate's December 1971 version as well. ${ }^{216}$ By early 1972, Congress began toying around with the idea of a completely new act rather than an amendment of the WPPDA, and soon thereafter introduced the Retirement Income Security for Employees Act, which again seemed to limit the relief to beneficiaries. ${ }^{217}$

It was not until January 1973 when fiduciaries finally made it into the remedial sections - albeit still as a modification to the WPPDAunder section 106(e)(2). ${ }^{218}$ Section 106(e)(2) limited this relief to that in section 111(d). Section 111(d) mirrored ERISA $\S 409$ with the same language expressly in favor of relief for the plans only. ${ }^{219}$ Several months later under Report No. 93-533, Congress kept the same available remedies as discussed in the earlier version under its new section 503(a)(2), but also gave fiduciaries the ability to "enjoin any act or practice which violate[d] any provision of [the] Act."220 The latter language appears again in a September 1973 version $^{221}$ and then in a February 1974 version. ${ }^{222}$

Congress then held hearings on the February 1974 version for the next few months - from February to June. Not one discussed cofiduciary contribution or indemnification. Finally, on August 13, 1974, the now troublesome language finally made its appearance, but the accompanying commentary lacked any discussion on the change. ${ }^{223}$ Instead, Senator Harrison Arlington Williams Jr., the Chairman of the Senate Committee

\footnotetext{
212. See H.R. 16462, 91st Cong. § 9(e) (1970), 1970 WL 123013.

213. Id.

214. See H.R. 1269, 92d Cong. § 106(e) (1971), 1971 WL 134914.

215. See H.R. 12337, 92d Cong. § 9(e) (1971), 1971 WL 134915.

216. See S. 3024, 92d Cong. § 9(e) (1971), 1972 WL 136895.

217. See S. 3598, 92d Cong. § 603 (1972), 1972 WL 136896.

218. See H.R. 2, 93d Cong. § 106(e) (1973), 1973 WL 172984.

219. Compare H.R. 2, 93d Cong. § 106(e) (1973), 1973 WL 172984, with ERISA § 409(a), 29

U.S.C. §1109(a) (2012). See also supra Section III.A.2.i.

220. See H.R. REP. No. 93-533 § 503(e)(3), at *52 (1973), 1973 WL 172986.

221. See H.R. 10489, 93d Cong. § 106(e)(3) (1973), 1974 WL 186654.

222. See H.R. 12781, 93d Cong. § 503(e)(3) (1974), 1973 WL 172998.

223. See S. REP. NO. 93-1090 § 502(a)(3), at*70 (1974), 1974 WL 186651.
} 
on Labor and Public Welfare, addressed the overall imposition of fiduciary duties on those managing assets by explaining its objectives:

[T]o make applicable the law of trusts; to prohibit exculpatory clauses that have often been used in this field; to establish uniform fiduciary standards to prevent transactions which dissipate or endanger plan assets; and to provide effective remedies for breaches of trust..$^{24}$

Note the understood distinction between making applicable the law of trusts to fiduciary duties and the provision of effective remedies.

Given the lack of discussion in the legislative history, it is clear that cofiduciary contribution and indemnification were nowhere near the forefront of Congress's mind when enacting ERISA. However, while the dive into the legislative history is not helpful in clearing up the ambiguity, it does shed light on the extent of the application of trust law principles to ERISA, i.e. for the benefit of participants or the plan rather than fiduciaries, an argument which will be more relevant in the discussion of federal common law.

\section{c. ERISA's Purpose}

Throughout the three sections in ERISA's declarations of policy, Congress set forth their main goal: the protection of employees and their beneficiaries. ${ }^{225}$ Congress strove to achieve this goal by requiring disclosure and reporting, setting standards of conduct for fiduciaries, vesting accrued benefits, setting minimum standards of funding and requiring termination insurance. ${ }^{226}$ From this language, courts also determined that ERISA sought to "safeguard the financial integrity of qualified plans by shielding them from unanticipated claims,"227 and "to encourage employers to offer and maintain welfare benefit plans." 228 Cofiduciary contribution and indemnification do not play any role in furthering these goals.

Contribution and indemnification do not influence disclosure and reporting. Contribution and indemnification also do not positively influence the standards of conduct for fiduciaries. In fact, the remedies may arguably reduce the watchdog effect joint and several liability creates among cofiduciaries. This is because the fiduciaries would be

224. 120 CONG. ReC. 29,932 (daily ed. Aug. 22, 1974) (statement of Sen. Williams).

225. See supra Section III.A.2.a.i-ii.

226. Id.; see also 29 U.S.C. § 1001(b)-(c) (2012).

227. Auto Owners Ins. v. Thorn Apple Valley, Inc., 31 F.3d 371, 375 (6th Cir. 1994).

228. Youngberg v. Bekins Co., 930 F. Supp. 1396, 1402 (E.D. Cal. 1996). 
aware that they could shoulder off any liability they incur from another more culpable fiduciary to that fiduciary (assuming the other fiduciary has deep pockets). Further, contribution and indemnification do not deal with vesting, funding, nor termination insurance. Finally, they do not help shield plans from unanticipated claims, and they do not affect the rights of the beneficiaries or the obligations under the plan.

Arguably, contribution and indemnification encourage employers to offer and maintain plans in the welfare plan context. For example, in the welfare context, the employer may benefit from indemnification if it can hold the administrator liable for any miscalculations of claims when the administrator bears sole responsibility for making those calculations. ${ }^{229}$ This benefit would incentivize employers to offer the plans. However, this purported purpose has only been raised by one district court in California (and even then, its conclusion has been severely critiqued by its own sister courts). ${ }^{230}$ Nonetheless, even if cofiduciary contribution and indemnification were to further this purpose, it would not further many others, and the likely negative effect on cofiduciary responsibilities would outweigh any small positives in the health and welfare context.

In sum, applying the Touche test reveals the following: first, the language of ERISA provides for some appropriate equitable remedies. Although contribution and indemnification are equitable remedies, however, their availability is limited to actions for the benefit of the plan or for the redressability of a breach of ERISA, rather than for the benefit of a breaching fiduciary. Second, the legislative history reveals that Congress never explicitly considered cofiduciary contribution or indemnification. Instead, the legislative history shows that Congress intended courts to develop ERISA with the breadth of trust law in determining the rights of participants under a plan and the duties of fiduciaries. Third, contribution and indemnification do not add to the statute's explicit purpose or further the majority of ERISA's purposes as developed by the courts. Given the ambiguous text, the silent legislative

229. Id.

230. Compare id. at 1402 (holding that Kim only applied to cofiduciary contribution and thus allowing a remedy for cofiduciary indemnification), with $\mathrm{Bd}$. of Trs. of Cal. Winery Workers Pension Tr. Fund v. Union Bank N.A., No. C 10-02240 SI, 2011 WL 1321602, at *6 (N.D. Cal. Apr. 6,2011 ) ("[T]he Court does not see a meaningful distinction between claims for contributionwhich are disallowed under Kim and Call — from those seeking indemnification for purposes of determining whether the common law of ERISA allows a right of action between co-fiduciaries."), Brown v. Cal. Law Enf't Ass'n, Long-Term Disability Plan, 81 F. Supp. 3d 930, 937 (N.D. Cal. 2015) ("[T]his case demonstrates why, in every case other than Youngberg, courts have declined to allow breaching fiduciaries to seek relief by complaining against other fiduciaries."), and Soohyun Cho v. First Reliance Standard Life Ins., No. CV 18-4132-MWF (SKx), 2019 WL 3243723, at *3 (C.D. Cal. Apr. 8, 2019) (distinguishing Youngberg from the case at hand). 
history, and their failure to further ERISA's explicit purposes, courts should not find implicit congressional authorization of contribution or indemnification in ERISA.

The next question is whether courts may develop these remedies into the ERISA common law.

\section{B. Federal Common Law}

The Supreme Court has recognized the need and authority to formulate ERISA common law using trust law principles. ${ }^{231}$ However, trust law principles are not necessarily determinative of whether ERISA should follow suit. ${ }^{232}$ In fact, in regards to remedies, the Court has also stated that courts should consider ERISA's carefully integrated scheme as "strong evidence that Congress did not intend to authorize other remedies that it simply forgot to incorporate expressly." 233 Some circuits have limited the circumstances in which they will develop this common law while others have laid out a set of factors to consider in determining whether to use this authority. Applying those facts and circumstances to contribution and indemnification, and considering the Court's abovementioned warnings reveals that the factors weigh in favor of not developing the federal common law.

Some circuits have held back from developing common law unless they found themselves required to fill in "interstitially" or otherwise effectuate the ERISA statutory pattern and purposes enacted by Congress. ${ }^{234}$ This more limited approach does not lie in favor of finding cofiduciary contribution and indemnification. Applying this principle, a court would have to examine the policies and purposes of ERISA. ${ }^{235}$ Similarly, a court should find that the policies are strictly limited to favoring beneficiaries and plan health. In doing so, a court should conclude that allowing fiduciaries to slack in their monitoring of other fiduciaries by relying on contribution or indemnification outweighs any benefits such remedies could bring, because even a more costly plan would be preferable to a disqualified one.

231. See Firestone Tire \& Rubber Co. v. Bruch, 489 U.S. 101, 110 (1989) (quoting Pilot Life Ins. Co. v. Dedeaux, 481 U.S. 41, 56 (1987)).

232. Varity Corp. v. Howe, 516 U.S. 489, 497 (1996) (“[W]e believe that the law of trusts often will inform, but will not necessarily determine the outcome of, an effort to interpret ERISA's fiduciary duties.").

233. Mass. Mut. Life Ins. Co. v. Russell, 473 U.S. 134, 146 (1985).

234. See supra note 131.

235. See supra Section III.A.2.c. 
The more liberal approach poses more of a problem. As the Sixth Circuit recognized, a court has the power to determine when it is appropriate for the court to fashion federal law in "instances in which (1) ERISA is silent or ambiguous; (2) there is an awkward gap in the statutory scheme; or (3) federal common law is essential to the promotion of fundamental ERISA policies." 236 Here, the first factor weighs in favor of developing the common law because ERISA is silent about cofiduciary contribution and indemnification. The two other factors, however, weigh against finding contribution or indemnification. It is unpersuasive to say that there is an awkward gap in the legislative scheme with respect to ERISA remedies. The Supreme Court has stated that the remedial section is long and complex, and provides strong evidence that Congress did not intend to authorize the missing remedies. ${ }^{237}$ Courts should not narrowly construe the Court's statement to extracontractual damages, as the Second and Seventh Circuit did in Chemung and Chesemore. Even if the courts narrowly construe the legislative history - the same legislative history that gave the courts the power to draft federal common law-provides that ERISA codified "certain principles ... of the law of trusts" —an implicit acknowledgment that Congress did not intend all trust principles to be part of ERISA. ${ }^{238}$ Additionally, ERISA carefully details the duties and liabilities of fiduciaries - the drafts of which are based heavily upon trust law. The omission was thus likely intentional, particularly given that the item omitted was some clearly established principle of trust law that Congress could not have missed when discussing fiduciaries. ${ }^{239}$ Finally, such remedies play no part in benefiting the plan or beneficiaries directly in accordance with the purposes set forth in the statute. While under the Sixth Circuit's factors only one factor is needed to develop federal common law. However, courts should consider that two of the three factors weigh against the development of ERISA remedies for cofiduciary contribution or indemnification and leave such work to the legislative process.

236. DiGeronimo Aggregates, LLC v. Zelma, 763 F.3d 506, 511 (6th Cir. 2014) (citing Local 60682 Int'l Union of Paper, All. Indus., Chem. \& Energy Workers v. Nat'l Indus. Grp. Pension Plan, 342 F.3d 606, 609 (6th Cir. 2003)).

237. Russell, 473 U.S. at 146.

238. S. REP. NO. 93-127, at *28 (1973), 1973 WL 172969.

239. See NARDA, Inc. v. Rhode Island Hosp. Tr. Nat'l Bank, 744 F. Supp. 685, 696 (D. Md. 1990) ("[W]hen some clearly established aspect of common law is not incorporated, the omission would appear intended."). 


\section{CONCLUSION}

By correctly analyzing the issues under the directives of the Court in Texas Industries and Touche, courts can confidently conclude not to allow contribution and indemnification as ERISA remedies. The analysis above allows for courts to both look for implicit congressional intent in the statute as written and to analyze their limited authority to develop ERISA federal common law. At the very least, the above analysis creates a structure for courts to use when addressing the question, instead of using procedural device theories, incomplete analysis, or placing too much emphasis on the common law arguments and ignoring any possibilities that congressional intent conflicts with their conclusions. It is noteworthy to consider how the Western District of New York, the district court which the Second Circuit reversed in Chemung, used this approach when it reached the same conclusion. ${ }^{240}$

However, just because ERISA does not provide for cofiduciary contribution or indemnification, it does not mean that fiduciary defendants are out of luck. An open question remains about whether these cofiduciaries may instead rely on claims for contribution or indemnification under state law liability theories or whether these claims are preempted by ERISA. The Eighth Circuit held the state law claims to be preempted, but some district courts have held the opposite. ${ }^{241}$ While such a discussion may be for another time, at the moment it should be clear that regardless of the philosophy of analyzing courts, courts should not find cofiduciary contribution or indemnification as implicit remedies in ERISA, and they should be reluctant to create these remedies through federal common law.

240. Chemung Canal Tr. Co. v. Sovran Bank/Md., 753 F. Supp. 81, 84-86 (W.D.N.Y. 1990), rev'd in part and aff'd in part by Chemung Canal Tr. Co. v. Sovran Bank/Md., 939 F.2d 12 (2nd Cir. 1991).

241. Compare Travelers Cas. \& Sur. Co. of Am. v. IADA Servs., Inc., 497 F.3d 862, 868 (8th Cir. 2007) (stating that "[t]o recognize a state-law cause of action that supplements the federal scheme in these circumstances would 'pose an obstacle to the purposes and objectives of Congress,' and state common-law claims are therefore preempted" (internal citations omitted)), with Spear v. Fenkell, No. 13-02391, 2014 WL 7745845, at *19 (E.D. Pa. Dec. 12, 2014) ("I conclude that Pennsylvania law applies, and that the Stonehenge Parties may assert a contribution claim under state law in response to the state law causes of action alleged in the Complaint."). 